\title{
THE FINAL JUDGMENT RULE IN ARIZONA
}

\author{
Thomas C. KLeinschmidT*
}

I

\section{INTRODUCTION}

The following is a broad review of the current civil law of Arizona concerning the requirement that court orders and judgments be final before they can be appealed.'

The right to appeal in Arizona exists only by force of statute and it rests solely within the discretion of the legislature to say in what cases and under what circumstances an appeal may be taken. ${ }^{2}$

Copyright (C) 1984 by Law and Contemporary Problems

* Judge, Arizona Court of Appeals. The author would like to thank Patricia Beaujean and Mark Calvert for their assistance with this article.

1. Some understanding of the Arizona judicial system may be helpful. The trial court of general jurisdiction is the superior court of which there is one for each county. Most superior courts have multiple divisions (judges) and in the most populous county in the state the superior court has over forty divisions. Below the superior court there are justices of the peace who preside over precincts within the county. Their jurisdiction is limited to small claims and misdemeanors. Towns and urban areas maintain municipal courts with jurisdictional limitations roughly similar to those imposed upon justices of the peace. The Arizona Court of Appeals is an intermediate appellate court and the Arizona Supreme Court is the tribunal of last resort. The structure and jurisdiction of Arizona courts are set forth in Article VI of the Arizona Constitution and title 12 of the Arizona Revised Statutes.

2. Him Poy Lim v. Duncan, 65 Ariz. 370, 181 P.2d 357 (1947). The statute which confers the right, ArIZ. Rev. Stat. ANN. $\$ 12-2101$ (Supp. 1983), provides:

Judgments and orders which may be appealed

A. An appeal may be taken to the court of appeals from the superior court in the instances specified in this section.

B. From a final judgment entered in an action or special proceeding commenced in a superior court, or brought into a superior court from any other court, except in actions of forcible entry and detainer when the annual rental value of the property is less than three hundred dollars.

C. From any special order made after final judgment.

D. From any order affecting a substantial right made in any action when the order in effect determines the action and prevents judgment from which an appeal might be taken.

E. From a final order affecting a substantial right made in a special proceeding or upon a summary application in an action after judgment.

F. From an order:

1. Granting or refusing a new trial, or granting a motion in arrest of judgment.

2. Granting or dissolving an injunction, or refusing to grant or dissolve an injunction or appointing a receiver.

3. Dissolving or refusing to dissolve an attachment or garnishment

G. From an interlocutory judgment which determines the rights of the parties and directs an accounting or other proceeding to determine the amount of the recovery.

H. From an interlocutory judgment in any action for partition which determines the rights and interests of the respective parties, and directs partition to be made.

I. From any interlocutory judgment, decree or order made or entered in actions to redeem real or personal property from a mortgage thereof or lien thereon, determining such right to redeem and directing an accounting. 
Judgments must be in writing, signed by the judge and filed with the clerk before they can be appealed. ${ }^{3}$ Rules relating to permission to appeal are to be strictly construed, ${ }^{4}$ but it is the substance of the court's order and not the name by which it is called that controls whether it is appealable. ${ }^{5}$

In order to present a clear and careful review of this rule and its effect and use in the Arizona courts, the most worthwhile approach is first to examine how the rule as to finality works predictably in several instances, then to examine an area of law where the courts have experienced considerable difficulty in applying the rule, and finally to observe an important exception to the rule.

\section{II}

\section{General Application of the Rule}

In broad terms a final judgment is one that disposes of a cause on its merits and leaves no question open for judicial determination. ${ }^{6}$ This definition of finality holds true even if the judgment does not expressly dispose of all parties and issues as long as it does so by necessary implication. ${ }^{7}$ An order made after judgment is not appealable if the appeal therefrom presents the same question that would have been presented on an appeal from the judgment. ${ }^{8}$

Another example of a commonsense application of the finality requirement is found in cases which hold that an order determining that a suit may be maintained as a class action is not an appealable decision while an order determining that it may not is appealable. ${ }^{9}$ In addition, orders sustaining the jurisdiction of the court are not final while those which dismiss for lack of jurisdiction are final. ${ }^{10} \mathrm{~A}$

J. From a judgment, decree or order entered in any formal proceedings under title 14

K. From an order or judgment:

1. Adjudging a person insane or incompetent, or committing a person to the state hospital.

2. Revoking or refusing to revoke an order or judgment adjudging a person insane or incompetent, or restoring or refusing to restore to competency any person who has been declared insane or incompetent.

L. From an order or judgment made and enterred on habeas corpus proceedings:

1. The petitioner may appeal from an order or judgment refusing his discharge.

2. The officer having the custody of the petitioner, or the county attorney on behalf of the state, from an order or judgment discharging the petitioner whereupon the court may admit the petitioner to bail pending the appeal.

M. If any of the orders or judgments referred to in this section are made or rendered by a judge they are appealable as if made by the court.

It should be noted that subsection $F(3)$ of the statute contrasts with existing federal case law which considers an order quashing attachment final for the purpose of appeal under 28 U.S.C. $\S 1291$ (1976), while an order refusing to quash is not appealable. See Swift \& Co. Packers v. Compania Colombiana Del Caribe S.A., 339 U.S. 684 (1950).

3. ARIz. R. Civ. P. 54(a), 58(a); Zoellner v. Zoellner, 4 Ariz. App. 561, 422 P.2d 392 (1967) (superseded by statute as stated in Barassi v. Matison, 130 Ariz. 418, 636 P.2d 1200 (1981))

4. Associates Fin. Corp. v. Scott, 3 Ariz. App. 1, 411 P.2d 174 (1966).

5. Properties Invest. Enters., Ltd. v. Foundation for Airborne Relief, Inc., 115 Ariz. 52, 563 P.2d 307 (Ct. App. 1977).

6. Id. at 54,563 P. $2 \mathrm{~d}$ at 308 .

7. Keystone Copper Mining Co. v. Miller, 63 Ariz. 544, 164 P.2d 603 (1945).

8. Reidy v. O'Malley Lumber Co., 92 Ariz. 130, 374 P.2d 882 (1962).

9. Compare Reader v. Magma-Superior Copper Co., 108 Ariz. 186, 494 P.2d 708 (1972) with Hanania v. City of Tucson, 123 Ariz. 37, 597 P.2d 190 (Ct. App. 1979).

10. London-Glasgow Dev. Co. v. Powers, 12 Ariz. 162, 100 P. 454 (1909). 
denial of a petition to intervene in an action is not considered final unless as a practical matter it denies the petitioner relief that he can only obtain by intervention. ${ }^{11}$

The Arizona statute specifically classifies certain interlocutory orders as appealable. Subsection C, for example, makes appealable a "special order made after judgment." An example of such an order is one granting a plaintiff's motion to reconsider and vacate a summary judgment entered for the defendants after the judgment has become final. ${ }^{12}$

Subsection $D$ of the statute allows an appeal from any order affecting a substantial right which in effect determines the action and prevents the entry of a judgment from which an appeal may be taken. The granting of a motion to dismiss without prejudice is an example of such an order. ${ }^{13}$

Subsection $E$ of the statute allows an appeal from a final order made in a special proceeding and affecting a substantial right. An illustration of its application is State $v$. Nerini, ${ }^{14}$ which held that an order quashing a complaint in an action to determine paternity was appealable. The statute which gave rise to the cause of action was silent both as to the right to appeal and as to the method of perfecting an appeal. The Supreme Court of Arizona rejected a challenge to its jurisdiction to decide the matter by simply observing that the matter was a "special proceeding." 15

Also included among appealable interlocutory decisions are orders directing an accounting, ${ }^{16}$ orders for the partition of property, ${ }^{17}$ and orders determining redemption rights. ${ }^{18}$

\section{III}

\section{Rule 54(B) of the Arizona Rules of Givil Procedure}

The application of the rule that allows for appeals when fewer than all the issues have been decided has given the Arizona courts considerable dificulty. Rule 54(b) of the Arizona Rules of Civil Procedure provides:

Judgment upon multiple claims or involving multiple parties. When more than one claim for relief is presented in an action, whether as a claim, counterclaim, cross-claim, or third-party claim, or when multiple parties are involved, the court may direct the entry of final judgment as to one or more but fewer than all of the claims or parties only upon an express determination that there is no just reason for delay and upon an express direction for the entry of judgment. In the absence of such determination and direction, any order or other form of decision, however designated, which adjudicates fewer than all the claims or the rights and liabilities of fewer than all the parties shall not terminate the action as to any of the claims or parties, and the order or other form of decision is subject to revision at any

11. Farmers' \& Merchants' Bank v. Arizona Mut. Sav. \& Loan Ass'n., 220 F. 1 (9th Cir.), cert. denied, 238 U.S. 628 (1915).

12. Engineers v. Sharpe, 117 Ariz. 413, 573 P.2d 487 (1977).

13. Edgar v. Garrett, 10 Ariz. App. 98, 456 P.2d 944 (1969).

14. 61 Ariz. 503, 151 P.2d 983 (1944).

15. Id. at 511,151 P.2d at 986 .

16. ARIz. ReV. Stat. ANN. § 12-2101(G) (1982).

17. Id. $\S 12-2101(\mathrm{H})(1982)$.

18. Id. § 12-2101(I) (1982). 
time before the entry of judgment adjudicating all the claims and the rights and liabilities of all the parties.

It is clear that, in the absence of an express finding that no just reason for delay exists, a judgment which adjudicates some claims or which is entered in favor of some but not all parties cannot be appealed. ${ }^{19}$ The absence of such a finding gives rise to the inference that the trial court has entered judgment subject to later modification. ${ }^{20}$

The development of the case law in recent years leads to the conclusion that trial courts in Arizona had traditionally been too liberal in finding "no just reason for delay" in the entry of final judgment. Since 1979, no fewer than three Arizona appellate decisions have admonished the trial courts for their excessively liberal or indiscriminate use of Rule 54(b) determinations. ${ }^{21}$ The warnings have apparently been taken to heart. In Continental Casualty Co. v. Superior Court, ${ }^{22}$ the Arizona Supreme Court dealt with a situation where the trial judge refused to enter a judgment containing Rule 54(b) language in a case where it was not only appropriate to do so but where all parties stipulated that the judgment as to several defendants should be final. Continental Casualty was a suit by an employee against his employer, coemployees, the compensation carrier insurance agency, and an insurer who provided liability coverage for property damage and bodily injury but excluded coverage for employees injured within the course and scope of their employment. The employee contended that the liability insurer had assumed a duty to inspect the employer's premises for dangerous conditions because it had conducted inspections of the premises in the course of assessing the risk and setting a premium. The trial court granted the insurer's motion for summary judgment and, ultimately, left pending only the action against the coemployees on the theory that they had negligently designed, operated, and inspected a forklift that had been involved in the injury. The supreme court concluded that the trial judge abused his discretion in refusing to include Rule 54(b) language in the judgment since the claims were brought on distinct legal theories and no appellate court would have to decide the same issue in the case more than once. This, it reasoned, would not offend the policy against piecemeal appeals. The court went on to note that if the judgment were subject to revision at any time before entry of judgment adjudicating all of the claims, the insurer would have to participate in all the litigation to avoid any risk of being inadequately prepared should the summary judgment in its favor be vacated.

Continental Casualty is a reaffirmation of the attempt to balance the judicial policy against piecemeal litigation with the policy of avoiding the unjust delay that can be occasioned by the liberal joinder rules. It appears to be the synthesis in the dialectic. Whether its simple guiding principle will allay the confusion in this area remains to be seen.

19. Tarnoff v. Jones, 15 Ariz. App. 88, 486 P.2d 200 (1971).

20. Stevens v. Mehagian's Home Furnishings, Inc., 90 Ariz. 42, 365 P.2d 208 (1961).

21. Pulaski v. Perkins, 127 Ariz. 216, 619 P.2d 488 (Ct. App. 1980); Watson Constr. Co. v. Amfac Mortgage Corp., 124 Ariz. 570, 606 P.2d 421 (Ct. App. 1979); Hill Bros. Chemical Co. v. Grandinetti, 123 Ariz. 84, 597 P.2d 987 (Ct. App. 1979).

22. 130 Ariz. 189,635 P.2d 174 (1981). 


\section{The Exception To The Rule-Special Actions}

The extraordinary remedies of certiorari, mandamus, and prohibition have always been available in Arizona. Certiorari and mandamus derive from the Arizona Constitution and from statute. ${ }^{23}$ Writs of prohibition derive from the constitution and the case law. ${ }^{24}$ Originally, writs of certiorari were intended only to test whether an inferior tribunal, board, or officer had exceeded its jurisdiction in situations where there was no plain, speedy, and adequate remedy by appeal. ${ }^{25}$ Writs of mandamus were intended to issue in order to compel the performance of a duty where there is no plain, speedy, and adequate remedy at law. ${ }^{26}$ Writs of prohibition were intended to issue in order to prevent an inferior tribunal from acting without jurisdiction or in excess of its jurisdiction, where injustice may ensue, and where there is no plain, speedy, and adequate remedy at law. ${ }^{27}$

Nineteen years ago, Robert O. Lesher, a former Justice of the Supreme Court of Arizona, observed that:

One who seeks the extraordinary writ moves in a murky world where statutes seem designed merely to confuse, where written rules are either incomplete or lacking entirely, and where the only path is in the footsteps of those who have gone before, a good many of whom have fallen off the edge. ${ }^{28}$

Lesher noted especially that the distinction between the purpose of certiorari and the purpose of prohibition was blurred. Since his observation, things have changed for the better, at least procedurally. In 1970 the Arizona Legislature promulgated the Rules of Procedure for Special Actions [Extraordinary WritsCertiorari, Mandamus, Prohibition]. ${ }^{29}$ The purpose of the change was to combine the traditional writs of certiorari, mandamus, and prohibition into one proceeding and thus to simplify the procedure for securing any writ. The rules were not intended to alter the substance of the various writs. ${ }^{30}$

Lesher noted, even before the new rules were adopted, that writs would issue to a lower tribunal for an abuse of discretion and that this was an expansion of the traditional use of writs to curb actions in excess of jurisdiction. ${ }^{31} \mathrm{He}$ observed that the use of the writs was moving in the direction of becoming a fast and cheap substitute for an ordinary appeal and that the Supreme Court of Arizona was already using the writs to correct "bad mistakes" where appeal was not considered a sufficient remedy. ${ }^{32}$ Such a trend's ramifications for the final judgment rule are

23. ARIz. Const. art. VI, $\S 4$; Ariz. Rev. Stat. ANN. $\S$ 12-2001 to -2007 (1982) (certiorari); ARIZ. Rev. Stat. ANN $\$ \S 12-2021$ to -2029 (1982) (mandamus).

24. ARIL. ConST. art. VI, § 4; Dean v. Superior Court, 84 Ariz. 104, 324 P.2d 764 (1958).

25. Welker v. Stevens, 82 Ariz. 233, 311 P.2d 832 (1957).

26. ARIZ. REv. StAT. ANN. § 12-2021 (1982).

27. Dean v. Superior Court, 84 Ariz. 104, 324 P.2d 764 (1958).

28. Lesher, Extraordinary Writs in the Appellate Courts of Arizona, 7 ARIz. L. REV. 34, 34 (1965).

29. Arizona Rules of Procedure for Special actions-[Extraordinary Writs-CertioRari, Mandamus, Prohibition] [hereinafter cited as Rules for Special actions ].

30. Rules fOR SPECIAL ACTIONS, supra note 29, 1 state bar committee note.

31. Lesher based his observations on State ex rel. Ronan v. Superior Court, 95 Ariz. 319, 390 P.2d 109 (1964), which held that a writ of certiorari could be used to test an abuse of discretion. He did not decry the trend towards a broader application of the writs.

32. Lesher, supra note 28 , at 49 . 
obvious.

It is still true, no doubt, that the supreme court continues to use special actions to correct "bad mistakes" where appeal is not considered a sufficient remedy. Since any kind of a case dealing with any area of the law may be the subject of a special action, it is difficult to search out, for the purposes of illustration, those cases which have come before the court as special actions. A few generalizations, however, are possible. First, where for some reason there is no statutory right of appeal the court has found a lack of a plain, speedy, and adequate legal remedy and will hear the case as a special action. ${ }^{33}$ Special actions are used to test orders of the trial court relating to discovery ${ }^{34}$ and to test the propriety of orders granting or refusing to grant changes of venue. ${ }^{35}$ Normally, the expense and delay of being put through a trial and appeal are not circumstances which will justify a special action, ${ }^{36}$ but in at least one case, Genda $v$. Superior Court, ${ }^{37}$ the supreme court heard a special action where the petitioner showed that a failure to enforce an order for the support of a mentally retarded boy would result in her inability to care for and provide a home for the boy. In Genda, the court noted a growing trend toward issuing extraordinary writs in order to test matters other than challenges to jurisdiction and it observed that the propriety of granting such writs depends upon the facts of each case. Citing a decision rendered two years earlier, the court said, "The guiding principle must be our obligation to see that essential justice is done."38 Pathos sped the law along in Genda.

Notwithstanding the trend away from the narrow use of the writs that began to develop at about the time of Genda, the special action in Arizona has not developed into the "fast and cheap substitute for appeal" that Lesher foresaw. While under the rules either the court of appeals or the supreme court may hear special actions from a lower tribunal, by virtue of an informal order of the supreme court, ${ }^{39}$ all special actions are heard in the latter tribunal. Hearings are set quickly and the chief justice may stay proceedings in the trial court pending the hearing. Following the hearing the supreme court may reject jurisdiction, ${ }^{40}$ that is, decline to decide the case on the merits. That is exactly what has happened in the vast majority of special actions presented for review. Statistics published by the supreme court for 1981 provide some insight into the frequency with which jurisdiction is granted and what types of cases are heard on special actions. ${ }^{41}$

33. Dean v. Superior Court, 84 Ariz. 104, 324 P.2d 764 (1958). This is, of course, logically at odds with the rule expressed in Him Poy Lim v. Duncan, 65 Ariz. 370, 181 P.2d 357 (1947), to the effect that the right to appeal is derived solely from statute, unless one interprets special actions and the writs themselves as derived from statute.

34. E.g., Dean v. Superior Court, 84 Ariz. 104, 324 P.2d 764 (1958).

35. E.g., Goff v. Superior Court, 2 Ariz. 344, 409 P.2d 60 (1965); Albins v. Superior Court, 7 Ariz. App. 264, 438 P.2d 333 (1968).

36. Caruso v. Superior Court, 100 Ariz. 167, 412 P.2d 463 (1966).

37. 103 Ariz. 240, 439 P.2d 811 (1968).

38. Id. at 242, 439 P.2d at 813 (quoting Caruso v. Superior Court, 100 Ariz. 167, 172, 412 P.2d 463, 466 (1966)). The supreme court later, in Helber v. Frazelle, 118 Ariz. 217, 575 P.2d 1243 (1978), disapproved of the substantive rule of decision applied in Genda. This, however, in no way reversed the trend to broader use of the writs.

39. Letter from Chief Justice Jack D. H. Hayes to Chief Judge Jacobson. (Sept. 24, 1974).

40. RUles fOr SPEcial Actions, supra note 29, 7(c).

41. Supreme Court of Arizona, The Arizona Courts - 1981 Annual Judicial Report (1981). 
In 1981 the Supreme Court of Arizona was presented with 177 petitions for special actions. In only twenty-seven (fifteen percent) of those cases did the court grant jurisdiction. ${ }^{42}$ Twelve of those cases in which jurisdiction was granted were criminal cases. ${ }^{43}$

The remaining fifteen civil cases can conveniently be broken down into three general categories. The first of these categories contains cases which the supreme court perceives as involving "statewide interest" where there is no plain and speedy remedy by appeal. Among these is Ross v. Superior Court, ${ }^{44}$ which involved the question whether an injured person whose claim had by operation of law been assigned to its Workman's Compensation carrier could accept a reassignment of the claim should the carrier decide not to bring an action based on it. This was no doubt deemed important for early resolution because of the great number of such claims at issue. Another case of the same type is Freightways, Inc. v. Arizona Corporation Commission ${ }^{45}$ which dealt with the Corporation Commission's attempt to deny the validity of a certificate of convenience and necessity that it had issued to a trucking company that presumably was conducting an ongoing business on a large scale. A somewhat similar case is American Bus Lines, Inc. v. Arizona Corporation Commission, ${ }^{46}$ which involved a petition to obtain relief from state regulation following the passage of a statute specifically deregulating the industry. Still others are McBride v. Superior Court ${ }^{47}$ which determined the effect of a statutory change in the amount of the legal rate of interest, and Tahtinen v. Superior Court ${ }^{48}$ which addressed the question of whether indigent prisoners may file civil rights actions in the superior court without paying filing fees. Three cases, also considered to be of statewide interest, dealt with interrelated questions concerning the disposal of school trust lands. ${ }^{49}$

\section{Id. at 23}

43. See State ex rel. Hyder v. Superior Court, 128 Ariz. 216, 624 P.2d 1264 (1981) (reviewing a judgment of acquittal granted by the trial court); State v. Grounds, 128 Ariz. 13, 623 P.2d 803 (1981) (reviewing a trial court order to reveal the name of an informant); State ex rel. Hamilton v. Superior Court, 128 Ariz. 184, 624 P.2d 862 (1981) (upholding a challenge to a public sexual indecency statute allegedly void for vagueness and noting that the matter was of statewide interest and that there was no plain and speedy remedy by appeal); State v. Superior Court, 128 Ariz. 535, 627 P.2d 686 (1981) (involving state's challenge to a dismissal of an indictment on the grounds that the statute under which it was brought was invalid); State v. Superior Court, 128 Ariz. 583, 627 P.2d 1081 (1981) (challenge to a ruling in limine precluding state's introduction of defendant's prior murder convictions as aggravating circumstances in resentencing); Rodriquez v. State, 129 Ariz. 67, 628 P.2d 992 (1981) (challenge to an order suppressing evidence); Galaz v. Carruth, 129 Ariz. 368, 631 P.2d 523 (1981) (determining whether counsel must be appointed in matters relating to post conviction relief); State ex rel. Collins v. Scott, 129 Ariz. 588, 633 P.2d 397 (1981) (challenge to a motion in limine precluding the admission of documents in evidence); Williams v. Superior Court, 130 Ariz. 209, 635 P.2d 497 (1981) (challenge to an order setting aside a plea agreement where acceptance of the plea placed the petitioner in jeopardy); Smith v. Superior Court, 130 Ariz. 210 , 635 P.2d 498 (1981) (petition to require the judge to impose a sentence in accordance with the plea agreement); State ex rel. Baumert v. Superior Court, 130 Ariz. 256, 635 P.2d 849 (1981) (challenge to a dismissal of indecent exposure charge on the ground that it had been compromised civilly).

44. 128 Ariz. 301, 625 P.2d 891 (1981)

45. 129 Ariz. 245, 630 P.2d 541 (1981).

46. 129 Ariz. 595, 633 P.2d 404 (1981).

47. 130 Ariz. 193, 635 P.2d 178 (1981)

48. 130 Ariz. 514,637 P.2d 723 (1981), cert. denied, 454 U.S. 1152 (1982).

49. Gladden Farms, Inc. v. State, 129 Ariz. 516, 633 P.2d 325 (1981); City of Sierra Vista v. Babbitt, 129 Ariz. 524, 633 P.2d 333 (1981); Arizona State Land Dep't v. Superior Court, 129 Ariz. 521, 522,633 P.2d 330, 331 (1981). 
A second category, represented in 1981 by a single case, involves a situation where the stakes were high and the issue would be rendered moot unless a decision was very quickly forthcoming. In Arizona Downs v. Superior Court, ${ }^{50}$ a corporation engaged in conducting horse racing meetings brought a special action to set aside a decision of the Arizona Racing Commission allocating to the plaintiff fewer racing days than it had sought. The racing season to which the order related was in progress at the time the action was begun.

A third category involves cases in which there would be an inordinate waste of time and effort if the trial court's ruling proved incorrect. In each case of this type the ruling complained of was entered before trial began. For example, in Cottonwood Estates, Inc. v. Paradise Builders, Inc., 51 the court reviewed an order of the trial court banning a particular attorney from trying the case, and in Morley v. Superior Court $^{52}$ the court considered an order which precluded a badly mutilated party from appearing at the liability stage of a bifurcated trial. Closely related to the preceding are cases which review discovery orders ${ }^{53}$ and a single case in which the court ruled that it was an abuse of discretion not to enter a final judgment in favor of one party for whom summary judgment had been granted in a multiparty case. ${ }^{54}$ One case, Equitable General Ins. Co. v. Helm, ${ }^{55}$ dealt with whether a judge abused his discretion in refusing to honor a notice of change of judge.

\section{V}

\section{CONCLUSION}

Since the Arizona Supreme Court has granted jurisdiction in special actions so sparingly, the procedure has never evolved into the fast and cheap substitute for appeal that Justice Lesher foresaw. Indeed, one might well speculate that it is the near certainty of a failure to persuade the supreme court to grant jurisdiction that makes the Arizona system work. A predictable lack of success appears to be limiting petitions for special action to a modest number. This predictability is rooted largely in the philosophy of a single five-judge court of stable composition. Whether the unfettered discretion bestowed by rules like those employed in Arizona would work well in the federal system, employing as it does many more appellate judges in different circuits, seems doubtful. The likely inability in the federal system to predict success or failure of an interlocutory appeal might well generate more such appeals and result in a confusing variety of jurisdictional criteria than would a more restrictive and defined system of rules.

50. 128 Ariz. 73, 623 P.2d 1229 (1981).

51. 128 Ariz. 99, 624 P.2d 296 (1981).

52. 131 Ariz. 85, 638 P.2d 1331 (1981).

53. Lipschultz v. Superior Court, 128 Ariz. 16, 623 P.2d 805 (1981); State ex rel. Hyder v. Superior Court, 128 Ariz. 253, 625 P.2d 316 (1981).

54. Continental Casualty Co. v. Superior Court, 130 Ariz. 189, 635 P.2d 174 (1981)

55. 128 Ariz. 6, 623 P.2d 365 (1981). 